\title{
INTENSITY AND PREVALENCE OF ECTOPARASITES IN TILAPIA (OREOCHROMIS NILOTICUS) SEEDS INFECTED WITH ECTOPARASITES THROUGH IMMERSION OF BINAHONG LEAF BOILED WATER (ANREDERA CORDIFOLIA)
}

\author{
CITRA PANIGORO ${ }^{1}$, JULIANA ${ }^{2} \&$ YUNIARTI KONIYO ${ }^{3}$ \\ ${ }^{1}$ Management of Aquatic Resources, Gorontalo State University, Indonesia \\ ${ }^{2,3}$ Aquaculture, Faculty of Fisheries and Marine Sciences, Gorontalo State University, Indonesia
}

\begin{abstract}
Ectoparasite is one of the causes of disease in freshwater fish, which often causes losses and freshwater fish farming failures. This study aims to determine the intensity and prevalence of ectoparasites in tilapia (Oreochromis niloticus) seeds through Binahong leaf (Anredera cordifolia) boiled water. The research method is an experimental method using a completely randomized design (CRD). The treatment was the long immersion of the binahong (Anredera cordifolia) leaf stew which consisted of four treatments, namelytreatment A (control / without immersion), B (5 minutes), C (10 minutes) and $D$ (15 minutes) with three repetitions. Data analysis performed using RAL. In this study, two types of ectoparasites fund to infect tilapia seeds, namely Cichlidogyrus sp and Trichodina sp. The results showed that the duration of immersion affected the intensity and prevalence of ectoparasites in infected tilapia (Oreochromis niloticus) fry. The best immersion time obtained in this study on the ectoparasite intensity of Cichlidogyrus sp and Trichodina sp is treatment B with immersion time of five minutes.
\end{abstract}

KEYWORDS: Binahong, Cichlidogyrus, Ectoparasite, Tilapia, Trichodina

Received: Dec 28, 2020; Accepted: Jan 18, 2021; Published: Jan 28, 2021; Paper Id.: IJMPERDFEB202112

\section{INTRODUCTION}

Tilapia (Oreochromis niloticus) is one type of freshwater fish that is popular in Indonesia and is widely cultivated by freshwater fish farmers. Tilapia Fish is a group of Tilapia which has morphological characteristics of an elongated, slender and relatively flat body. Habitat Tilapia is usually found in shallow or deep fresh water and especially in vast waters. Tilapia also typically live in rivers, reservoirs, lakes, swamps, brackish water, and seas that do not have a water flow that is not too fast. The habitat of tilapia is spread from freshwater to marine waters. Tilapia is a fish that tends to be omnivorous because in general waters the leading food is plankton. Tilapia is also a fish that experiences fast growth, so it is perfect for cultivation.

One of the factors that must be considered in the success of fish farming is the presence of disease attacks in cultivated fish. One of the causes of disease in fish is a parasitic attack on the fish. Infections in fish can arise due to low environmental quality or due to parasitic attacks on fish. The environment is not right and parasite attack on fish can inhibit the growth of fish and even cause death in farmed fish. Disease or parasite attack on fish can occur in hatchery activities or in fish rearing (Yuliarti, 2011) 
Parasites in fish are organisms that live in farmed fish, where the parasites usually take food from the fish's body so that that fish growth can be disturbed. One group of parasites that can cause disease in fish is ectoparasi. Ectoparasites is a type of parasite that attacks fish on the surface of the skin, fins and gills. Fish diseases caused by parasites can cause a decrease in the quality of the fish and health problems in humans who consume the fish. The presence of parasites can cause deadly effects on host populations and consequently can cause significant harm to the fishing industry (Palm et al., 2008).

Bhakti et al (2011) stated that the causes of disease in fish are very diverse, one of which is ectoparasites in fish. Ectoparasites can be one of the predisposing factors for infection with more dangerous pathogenic organisms. The attack of ectoparasites makes the fish lose their appetite, then slowly become weak and lead to death. Ectoparasites infect the fins, scales, operculum and gills of fish. Several factors that play a role in disease attack in fish are the density of fish cultivated in monoculture and stress, as well as biotic and abiotic factors, namely physical and chemical factors in water and various pathogenic organisms (Wiraruddin and Eliawardani, 2007).

Generally, fish that live in free waters can be infected by various types of ectoparasites such as Monogenea, Digenea, Nematoda and Acanthocepala. The types of ectoparasites that often attack tilapia (O. niloticus) are Trichodina sp .; Dactylogyrus sp .; Gyrodactylus sp .; Ichtyopthirius mulrifilis sp .; Lernaea sp .; and Myxobolus sp.is an ectoparasite that commonly attacks tilapia, living on the gills, skin and on the fish's fins. Fish infected with ectoparasites generally have gills and pale skin, excessive mucus production occurs, frayed fins and opaque corneas.

Ectoparasite attack on fish causes less damage or attack compared to other viruses and bacteria. Ectoparasite infection only attacks the external parts of the fish, but ectoparasite attack can cause death in fish if not handled quickly and accurately. Many methods of handling diseases due to ectoparasite attack in fish have been done both chemically and non-chemically. Chemical treatment is starting to be limited because it can cause residues in the waters or fish habit, which can cause pollution or reduce water quality.

One way that has been developed to deal with ectoparasite attacks in fish is by utilizing ingredients containing antibacterial compounds derived from plants. Binahong (Anredera cordifolia) is a type of plant that has the potential to be used as an alternative material to treat ectoparasite attacks in fish. Binahong (Anredera cordifolia) is a plant that has characteristics such as round-shaped leaves, lives by propagating its stems, and has a sexual and vegetative reproductive system.

Binahong (Anredera cordifolia) through pharmacological tests found that this plant can act as antibacterial, antiobesity, antihyperglycemic, anti-inflammatory (Kurniawan, 2012). According to Umar et al (2102), binahong contains antibacterial compounds, namely saponins, alkaloids, polyphenols, thanin, flavonoids, and essential oils. The content of these compounds makes binahong able to be used as an antibacterial. Based on the range of these compounds, it is necessary to test the intensity and prevalence of ectoparasites that attack tilapia.

\section{RESEARCH METHODS}

The materials used in this study were binahong leaves (Anredera cordifolia), tilapia seeds (Oreochromis niloticus) measuring $\pm 5 \mathrm{~cm}$ and identified as being attacked by ectoparasites, fish feed and clean water as a living medium for fish. The binahong leaves used are bright green leaves and not too old, then boil them with water. The tools used are aquariums, analytical scales, binocular microscopes, pH meters, DO meters, Erlenmeyers, blowers, thermometers, hoses and aerated 
stones. The aquarium used is 12 units and measures $20 \times 20 \times 30 \mathrm{~cm}$.

The research method is an experimental method using three replications and four treatments. Tilapia seeds were used as many as 10 treatments consisting of treatment A, namely without immersion (control), treatment B soaking for five minutes, treatment $\mathrm{C}$ soaking for 10 minutes, and $\mathrm{d}$ of therapy soaking for 15 minutes. Fish seeds infected with ectoparasites were soaked according to treatment using binahong leaf boiled water with a concentration of $30 \mathrm{ppm}$. The soaked seeds were maintained for a week to observe the intensity and prevalence of ectoparasites in tilapia seeds after being treated.

The variables observed were intensity and ectoparasites found in fish seeds after giving treatment. The variable is calculated using the following equation (Kabata, 1995):

$$
\begin{aligned}
& P=\frac{\sum \text { diseased fish }}{\sum \text { Check up the fish }} \times 100 \% \\
& I=\frac{\sum \text { Ectoparasites }}{\sum \text { Check up the fish }} \times 100 \%
\end{aligned}
$$

Where:

P: Prevalence (\%)

I: Individual (Tail.ltr_1)

Data analysis was carried out using a complete apparatus design (CRD) to determine the effect of immersion time in binahong leaf boiled water on tilapia seeds infected with endoparasites. The data obtained were analyzed using the following formula (Gaspers, 1991):

$$
\boldsymbol{Y}_{i j}=\mu+\tau+\varepsilon_{i j}
$$

Information:

Yij : Response to the ith treatment in the jth test

$\mu$ : Observation average

$\tau$ : The effect of the i-tested treatment

$\varepsilon_{\mathrm{ij}}$ : Experimental error from treatment $\mathrm{i}$ to observation $\mathrm{j}$ 


\section{RESULTS AND DISCUSSIONS}

\section{Result}

\section{Ectoparasite Intensity}

The results showed that from 60 seeds infected with ectoparasites, two types of ectoparasites were found, namely one genus from Ciliata, namely Trichodina sp., And one genus from Monogenea, namely Cichlidogyrus sp. The ectoparasite intensity in fish seeds that had been treated gave different results. The ectoparasite intensity of Trichodina sp. Was higher than the ectoparasite intensity of Cichlidogyrus sp. The highest ectoparasite intensity was obtained in treatment A while the lowest was in treatment B. The detailed ectoparasite intensity in each treatment is presented in Figure 1.



Figure 1: Ectoparasite Intensity in Tilapia Seed

Based on the obtained ectoparasite intensity values, the data were analyzed using RAL to determine the effect of immersion time. The results of the RAL analysis showed that the immersion time had an impact on the ectoparasite intensityTrichodina sp and ectoparasites Cichlidogyrus sp (Table 1 and Table 2).

Table 1: Results of RAL Analysis for Ectoparasite Intensity of Trichodina sp

\begin{tabular}{|c|c|c|c|c|c|}
\hline SK & db & JK & KT & Fhit & $\begin{array}{r}\text { Ftable } \\
0.05 \\
\end{array}$ \\
\hline Treatment & 3 & 2276.25 & 748.8 & & \\
\hline Error & 8 & 30 & 3.75 & & \\
\hline Total & 11 & 2246.25 & 199.67 & $36.47 * *$ & 4.07 \\
\hline
\end{tabular}


Table 2: Results of RAL Analysis for Ectoparasite Intensity of Cichlidogyrus sp

\begin{tabular}{|c|c|c|c|c|c|}
\hline & & & & & Ftable \\
\hline SK & db & JK & KT & Fhit & 0.05 \\
\hline Treatment & 3 & 1586.25 & 528.8 & \multirow[b]{3}{*}{$36.47 * *$} & \multirow[b]{3}{*}{4.07} \\
\hline Error & 8 & 116 & 14.5 & & \\
\hline Total & 11 & 1702.25 & & & \\
\hline
\end{tabular}

\section{Ectoparasite Prevalence}

The results also showed that the prevalence of fish attacked by Trichodina sp. Ectoparasites were higher than the majority of fish attacked by Cichlidogyrus.sp. The highest prevalence of fish attacked by Trichodina sp ectoparasites was $100 \%$, while the lowest was $33.33 \%$. The highest prevalence of bacteria attacked by Cichlidogyrus sp ectoparasites in fish seeds was $83.33 \%$, and the lowest was $16.67 \%$. The majority is the percentage of fish attacked by bacteria after the treatment was given; this shows that each treatment provides a different prevalence. The prevalence of each treatment is presented in detail in Figure 2.

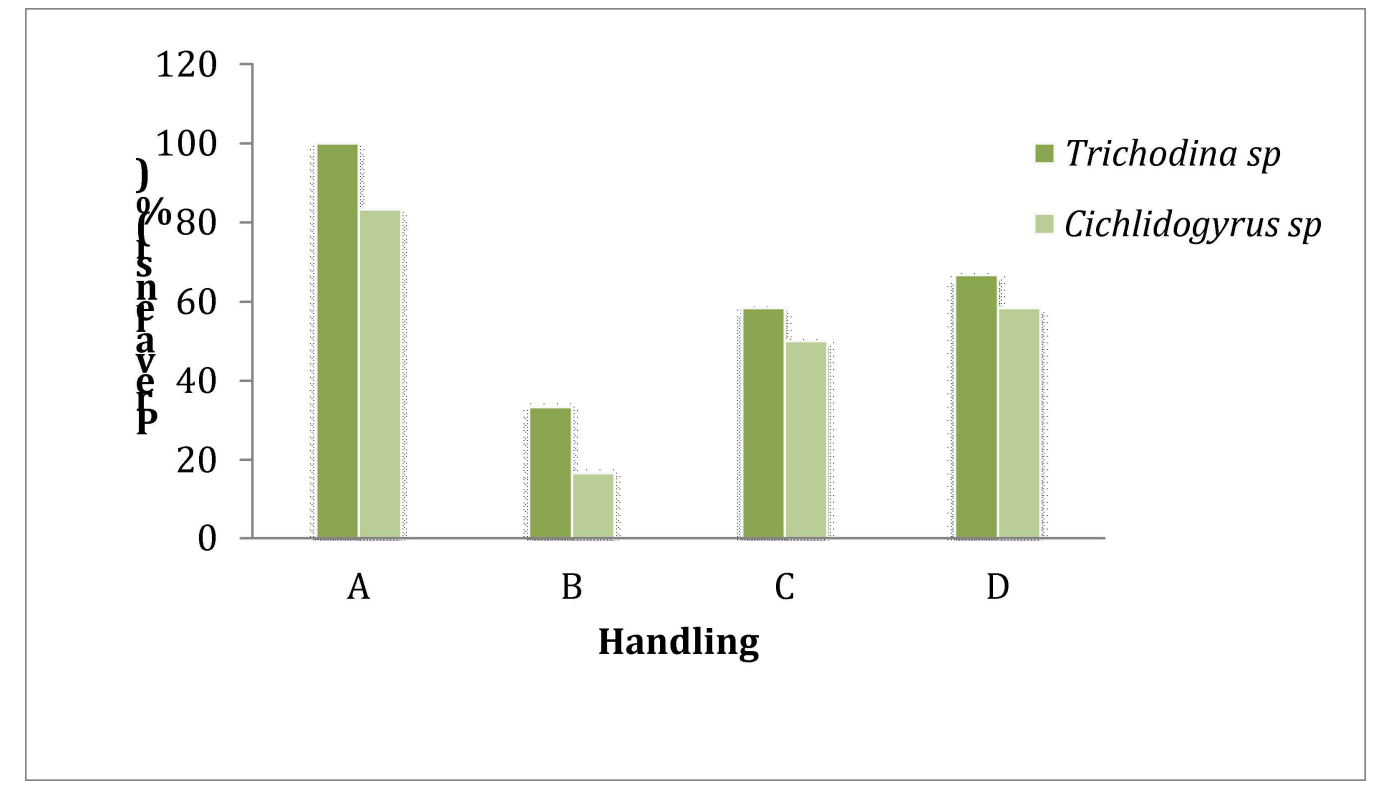

Figure 2. The Prevalence of Ectoparasites in Tilapia Seeds

Based on the prevalence value of ectoparasites, to determine the effect of the duration of immersion, RAL analysis was performed. The results of the RAL analysis state that the time of immersion has an impact on the prevalence of ectoparasites Trichodina sp and ectoparasites Cichlidogyrus sp. The results of the RAL analysis are presented in Table 3 and Table 4. 
Table 3: Results of Trichodina Prevalence RAL Analysis

\begin{tabular}{|c|c|c|c|c|c|}
\hline & & & & & Ftable \\
\hline SK & db & JK & KT & Fhit & 0.05 \\
\hline Treatment & 3 & 7239.58 & $2,413.2$ & \multirow[b]{3}{*}{904.95} & \multirow[b]{3}{*}{4.07} \\
\hline Error & 8 & 21.33 & 2.7 & & \\
\hline Total & 11 & 7260.92 & & & \\
\hline
\end{tabular}

Table 4: Results of RAL Analysis of the Ectoparation Prevalence of Cichlidogyrus sp

\begin{tabular}{|c|c|c|c|c|c|}
\hline & & & & & Ftable \\
\hline SK & $\mathrm{db}$ & JK & KT & Fhit & 0.05 \\
\hline Treatment & 3 & 9520.25 & $3,173.4$ & \multirow[b]{3}{*}{32.55} & \multirow[b]{3}{*}{4.07} \\
\hline Error & 8 & 780 & 97.50 & & \\
\hline Total & 11 & 10300.25 & & & \\
\hline
\end{tabular}

\section{DISCUSSIONS}

- Fish disease is a problem that is often found in aquaculture, especially in the size of the seeds to enlargement. One of the disease attacks on fish is parasites. Parasites are organisms that live on other organisms that take food from the organism's body so that the organism where they eat (host) will suffer losses. Parasitism is a relationship with a parasite species where the host is a habitat and is a place to obtain food or nutrition, the host body is the primary environment for parasites while the surrounding environment is the second environment (Yuliarti, 2011)

- Trichodina sp. is one of the parasites that often attacks farmed fish, especially on the skin and gills. Trichodina sp. is often found in freshwater fish seeds (Taufik et al., 2003). These parasites can penetrate into the gill lamellae and penetrate into the blood vessels, causing bleeding. The wounds inflicted can cause balance disorders, disturbing breathing and cause death (Cahyono et al., 2006). Trichodina feeds on bacteria and other water particles and will turn parasitic if there is a lack of food.

- Based on the results of observations on tilapia scales using a microscope, Trichodina sp. is a protozoan in the shape of a round disc-like bowl. Trichodina sp. round (flat disc) with a lateral side (adoral zone) shaped like a bell, there are cilia around the body except in the adoral area, has a denticle ring as an attachment tool. When swimming, it looks like the motion of a flying saucer spinning. This is similar to that reported by Onhoiulun (2002), who found Trichodina spp. Predilected in the skin, fins, and operculum of fish, which have the characteristics mentioned. The parasite that infects tilapia, Trichodina, is a type of ectoparasite, according to Anshary (2008). The highest infection and parasite intensity were Trichodina parasites. Trichodina parasites were found in all fish samples. 
- Cichlidogyrus sp. is a parasite that infects tilapia seeds in the Fish Seed Center (BBI) of Gorontalo City. Chichlidogyrus sp. included in the monogenous group, these parasites release eggs, and after hatching will become free-swimming larvae called oncomiracidia and infect the host within a few hours. After reaching the host this parasite migrates to the target organ and develops into an adult parasite.

- Chichlidogyrus sp. is a monogenea found in the gills of tilapia at Fish Seed Center (BBI) apart from Trichodina sp .. Cichlidogyrus sp. This will be found in fish gills in non-ideal environmental conditions, low water quality and when the fish are under stress. Cichlidogyrus sp. attaches to the gill filaments and feeds on gill epithelial cells, mucus and blood on the gills. This can lead to death for tilapia that is still young or weak due to stress and acute infection.

- Cichlidogyrus sp causes clinical symptoms, namely pale gills, hyperplasia of the gills and increased mucus secretion, and redness of the affected area. Wawunx (2008) in Yuliartati (2011) states that the location of the gills, structure and contact mechanisms with the environment makes gills very vulnerable to changes in environmental conditions and is the right place for infection to take place by disease-causing pathogenic organisms such as parasites. Fish infected with the parasite Cichlidogyrus sp, have pale gills and skin, excessive mucus production, frayed fins and opaque corneas; the severe infection causes hyperflasia of the gill epithelia and skin, severe damage to the gills makes it difficult for the fish to breathe and can cause death (Anshary, 2008).

- In this study, Binahong leaf boiled water immersion was used to control ectoparasites found in tilapia seeds. Based on the results of the study, it was stated that the soaking time had an effect on the intensity and prevalence of ectoparasites in Tilapia seeds. This is in line with the results of research which says that binahong leaves contain alkaloid compounds, polyphenols, flavonoids, saponins, and anthraquinones, where these compounds can be used as antibacterial agents (Katno et al., 2006). The results of other studies also indicate that plants binahong can be an inhibitor against Staphylococcus aureus ATCC 25923. The results of phytochemical screening show that petroleumeter, ethyl acetate, and $70 \%$ ethanol extract of binahong rhizoma contains alkaloids, saponins, flavonoids and polyphenols (Setiaji, 2009).

- Research on the wound healing activity of binahong leaves and their secondary metabolite content has been carried out, that in binahong leaf simplicia contains flavonoids, tannins, and saponins compounds [Kurniawan, 2012]. The flavonoid compounds found in binahong leaves can act directly as antibiotics by disrupting the function of microorganisms such as bacteria and viruses. (Manoi, 2009). Tannins can shrink the cell wall or cell membrane so that it interferes with the permeability of the cell itself. As a result, permeability is disrupted, cells cannot carry out living activities so that their growth is stunted or even dies (Ajizah, 2004). Saponins have the ability to clean and stimulate the formation of the first collagen, which is a protein that plays a role in wound healing (Hidayati, 2009).

\section{CONCLUSIONS}

The results showed that the immersion time of binahong leaf (Anredera cordifolia) boiled water affected the intensity and prevalence of ectoparasites Trichodina sp and Cichlidogyrus sp in infected tilapia (Oreochromis niloticus) seeds. 


\section{REFERENCES}

1. Ajizah, A. 2004. The sensitivity of Salmonella Typhimurium Against Leaf Extract. Vol. 1. No. 1: 31-8. Psidium Guajava L. Bioscientiae

2. Bhakti, S. Arimbi. And Kusnoto. 2011. Ectoparasite Prevalence and Identification in Koi Fish (Cyprinus carpio) in Several Ornamental Fish Cultivation Locations in East Java. Airlangga University Faculty of Veterinary Medicine. Surabaya.

3. Gaspersz, V. 1991. Experimental Design Methods. CV.ARMICO.

4. Hidayati Isnaini Wahyu. 2009. Activity Test of Binahong Leaf Extract Ointment (Anredera cordifolia (Ten.) Steen) as a Healing Burns on Rabbit's Back Skin. [Thesis]. Faculty of Pharmacy: Muhammadiyah University of Surakarta.

5. Bandung.Handayani, H. 2005. Fish Parasites and Diseases. Muhammadiyah University of Malang.

6. Kabata, Z. 1985. parasites and disease of fish cultured in the tropics. Taylor and Francis, London, UK.

7. Katno, Dyah Subositi, Rohmat Mujahid, and Harto Widodo, 2006, Inventory of Indonesian Medicinal Plants, Edition VI, Jakarta, Department of Health, Research and Development Agency for Health Research Institute for Medicinal Plants. Pp. 1617.

8. Kurniawan, B., N. Carolia, A. Sukohar, and APY Thamrin. 2012. Anti-Inflammatory Effectiveness Test of Binahong Leaf Extract (Anredera cordifolia (Ten.) Steenis) in Carrageenan-Induced Sprague Dawley Rats. Medical Faculty of Lampung University. 8 p.

9. Manoi, F. 2009. Binahong (Anredera cordifolia) as medicine. Journal of Industrial Crops Research and Development 15 (1): $3-4$

10. Palm, B., M. Damriyasa, Linda, and Oka. 2008. Molecular genotype of Anisakis. Helminth Journal. 4 (1): 3-12.

11. Setiaji, A., 2009, Antibacterial Activity Test of Petroleum Ether Extract, Ethyl Acetate, and 70\% Ethanol Rhizoma Binahong (Anredera cordifolia (Tenore) Steen) against Staphylococcus aureus ATCC 25923 and Phytochemical Screening, Thesis, Faculty of Pharmacy, UMS, Surakarta.

12. Wiraruddin and Eliawardani. 2007. Inventory of ectoparasites that attack goldfish raised in floating nets in Danau Laut Tawar, Central Aceh Regency. Journal of Veterinary Medicine. Vol. 1. no. 2.

13. Yuliartati, E. 2011. Ectoparasite attack rate on catfish (Pangasius djambal) in several fish cultivators in Makassar City. Thesis. Hasanuddin University Faculty of Marine and Fisheries Sciences. Macassar. 